\title{
The Role and Priorities of the Human Resource Management Function: Perspectives of HR Professionals, Line Managers, and Senior Executives
}

\author{
Sunil Ramlall, Ph.D.
}

USA

\author{
Becky Melton, Ph.D. \\ HR Faculty, Western Governors University, USA
}

Received: Feb. 5, 2019 Accepted: Mar. 1, 2019 Online published: Mar. 13, 2019

doi:10.5296/ijhrs.v9i2.14492

URL: https://doi.org/10.5296/ijhrs.v9i2.14492

\begin{abstract}
How do HR professionals, Line Managers and non-HR Senior Executives view HR strategies? What are the main deliverables of HR activities as viewed by the different groups? What level of importance is placed on HR practices by the respective groups? What are the implications for the HR function? What gaps exist among the stakeholder groups of HR relating to the importance of HR? How can there be more synergy of HR practices among the stakeholder groups?

Unlike previous research studies, this study examines a more holistic view of HR and the level of importance placed on the respective strategies. The findings not only identify the major accomplishments of HR and alignment to business strategies but also highlight several key areas in which there is a significant gap in emphasis and importance as viewed by different stakeholders.
\end{abstract}

Keywords: strategic HR, perspective of HR, alignment of HR and strategy, human capital, and firm performance

Strategic human resource management (SHRM) research focuses on the contribution that HR practices can make to organizational performance and competitive advantage (Mitchell, Obeidat, \& Bray, 2013). Within this research context, the role of HR management as a strategic partner with influence in organizational and HR strategic decision-making has growing importance (P. Wright, Gardner, Moynihan, \& Allen, 2005). Dave Ulrich explained that HR is about creating value for others, managing talent, and leadership and culture, the 
three areas that distinguish great organizations from the merely good ones (Gyton, 2017).

So how do HR professionals, Line Managers and non-HR Senior Executives view HR strategies? What are the main deliverables of HR activities as viewed by the different groups? What level of importance is placed on HR practices by the respective groups? What are the implications for the HR function? What gaps exist among the stakeholder groups of HR relating to the importance of HR? How can there be more synergy of HR practices among the stakeholder groups? Unlike previous research studies, this study examines a more holistic view of HR and the level of importance placed on the respective strategies. The findings not only identify the major accomplishments of HR and alignment to business strategies but also highlight several key areas in which there is a significant gap in emphasis and importance.

Recent HR differentiation research has been concerned with HRM differences within job and HRM differences between job groups of different strategic value (Krausert, 2017). Less attention has been paid to HR differentiation among strategically valuable job groups. This research bridges the research gaps of identifying and differentiating the perspectives of HR among three critical stakeholder groups to include HR Professionals, Line Managers, and non-HR Senior Executives.

\section{Background and Theory}

With global achievement in today's business world of dynamic and proficient interchange about an idea, a sustainable competitive advantage is no longer ingrained in an organization visible resources, but a core part of a firm's human resources (Halawi, Mccarthy, \& Aronson, 2008). The most frequently named theory for describing the relationship in strategic HRM practices is a behavioral approach which postulated that divergent role behaviors are essential for various kinds of strategies that an organization pursues (Jackson \& Schuler, 1987).

\section{Strategic HRM Practices and the Impact on Company Performance}

Much debate has centered on the impact of strategic HRM on organizational performance. Through research, discussions with HR professionals, Line managers, and Senior Executives, there have been varying levels of perspectives on the focus of HR, time spent on various HR activities, and the deliverables of the HR strategies. Researchers have argued that human resources may be seen as a source of sustained competitive advantage for organizations (Barney, 1991; B. Becker \& Huselid, 1998; B. Becker, Huselid, \& Ulrich, 2001). The underlying assumption is that human resources are unique to the extent that competitors cannot imitate them (Akhtar, Ding, \& Ge, 2008).

Strategic HRM practices enhance both individual and organization performance, and employees that are well trained and motivated are more committed and willing to spend extra effort to achieve superior performance (Brian Becker \& Huselid, 2006). The major distinction connecting strategic HRM practices and HRM is the adoption and integration of strategic decisions into HRM procedures and plans to manage organization performance (Guest, 1989). Delery and Doty (1996) identified seven such practices that have been consistently considered strategic HRM practices. They defined strategic HRM practices as those that are "theoretically or empirically related to overall organizational performance" (p. 805). 
Significant research attention has been devoted to examining the relationship between HR practices and firm performance, and research support has assumed HR as the causal variable (P. Wright et al., 2005). Given that there is some degree of consensus that one source of sustainable competitive advantage for progressive organizations has been the HR function, scholars have devoted a great deal of attention to examining the linkage between HR practices and firm performance. Based on previous research, it has become clear that the HR system is one important component that can help an organization become more effective and achieve competitive advantage (B. Becker \& Huselid, 1998).

\section{HR as Strategic Business Partner}

There has been tremendous debate and improvements to the practice of HR in the past decade. In the end, HR effectiveness is not a self-perceived judgment but instead as viewed by HR and all stakeholder groups. Transforming HR professionals into business partners is not just reflecting HR practices in a strategic mirror, but looking through the strategy to external constituents and connecting HR inside the firm to expectations of those outside the firm (Younger \& Ulrich, 2011).

To be seen and valued as 'strategic' and a 'business partner' is the desire of most organizations' HR functions. Although this aim has been discussed in numerous studies over many years (see e.g. Ulrich et al. 1995; Ulrich 1996), we believe that the discussion should be ongoing, as HR practitioners continue to face this challenge. Generally, gaining a strategic position and a business partner role is seen as being built on HR competencies (Laine, Stenvall, \& Tuominen, 2017).

A recent study by Emeagwal \& Ogbonmwan (2018) suggested that strategic HRM practices are indicators of a sustainable competitive advantage further enhancing the development of human capital and employee commitment. Their results suggested that strategic HRM practices motivate human capital development and employee commitment, while they enhances sustainable competitive advantages.

"To be seen as strategic business partners, the HR profession must evolve to the next level: organizational effectiveness." (Jamrog \& Overholt, 2004). The authors explain that organizational effectiveness deals with the ability of the organization to successfully achieve its' intended mission. They further explain that to understand the impact of HR on organizational effectiveness, a systems thinking and a systems measurement must be embraced. As Stopper (2005) said, from an HR standpoint, this is new territory for some and deserves both thought and action. Indeed, this is a highly necessary component of the HR curriculum and provides a solid framework for organizational performance.

\section{Perceptions of Senior Leadership and Line Managers of HR}

The HRM professional is now expected to assume a prominent position at the senior decision-making level and to take a proactive role in developing the organization's people as a source of competitive advantage (Cascio, 2005; Roehling et al., 2005; Wright \& Snell, 2005). In an analysis of the roles for the HRM professional, Ulrich (1997) has argued that HRM has to offer expertise in the traditional operational roles of administrative expert and 
employee champion as well as developing skills in the more recent strategic roles of change agent and strategic partner. More recently, Ulrich and Brockbank (2005) have revisited the definition of roles and have made some variations to the terms used.

\section{Methods}

\section{Sample and Data Collection}

Data were obtained from HR Professionals, Line Mangers, and Senior Executives across the United States representing 149 unique companies. A stratified sampling method was used to ensure participants were representing as many industries, different tenure in position, professional interests, and gender. The participants were asked to complete the questionnaire using SurveyMonkey. Participation was completely voluntary.

The questionnaire was sent to a total of 326 professionals. A total of 149 responses were received, representing a 44.5 percent response rate. A brief synopsis of HR's role was also included with the survey. In completing the survey, participants were asked to respond to questions focusing on the main deliverables of HR activities as viewed by the different groups, level of importance placed on outcomes of HR (around talent, leadership, and organization), practices of HR (around managing people, performance, information, and work), and stakeholders for HR (employees, organization, customers, and investors). In addition, data were collected about firm performance, individual performance, industry and firm data, and general demographic information.

Of the 149 participants, 41 identified themselves as HR professionals, 35 as Individual Contributors, 26 as Line Managers, and 47 were Senior Executives. Of all participants, approximately $8.5 \%$ had a high school diploma, 9.5\% had an Associates degree, $30 \%$ had a Bachelors Degree, 28\% had a Masters/MBA, and 24\% had a Doctorate degree. This sample represented an inclusive variety of educational background.

\section{Measures}

Board Relations. The past few years have brought some remarkable changes to the role of U.S. corporate boards, resulting in an intriguing paradox for chief human resource officers (CHROs) (Nadler \& Nadler, 2015). As more boards immerse themselves in both operational details and rigorous risk oversight, HR should be showing up on the board's radar more often than ever before. Chen (2015) explained that despite all that has been written and studied from HR's perspective in recent years, directors - at least those who participated in our survey - still view HR pretty much as they always have: a very transactional support function that often does a terrific job on compensation and benefits, but one which is not perceived as playing a more strategic role in the boardroom. The results depict HR as still pigeon-holed in a very tight, tactical box, but viewed as generally irrelevant or lacking in major influence when it comes to strategic issues that top the board's agenda.

Build HR Function. Previous research revealed seven generic roles that comprise the overall CHRO job. These are Talent Architect, Strategic Advisor, Counselor/Confidante/ Coach, Leader of the HR Function, Liaison to the Board, Workforce Sensor, and Representative of 
the Firm (Patrick Wright, Nyberg, Schepker, Cragun, \& Ulrich, 2016). This measure sought to gauge the level of priority for building an HR function as viewed by the respective stakeholder groups.

Coach and Build Executive Management Team. How important is it to coach and build the Executive Management Team? Today, leadership is extremely important for development and future prospects of modern companies (Glamuzina, 2015). Management and leadership are interconnected and they complement each other in every organization, which means that both leadership and management contribute to reaching organizational objectives (Drucker, 2004). To what extent is this an important activity of HR?

Compensation. Compensation is a connecting factor that brings the employee and organizational goals together. It impacts a critical issue that many organizations face today, and that is talent retention. It is a bridge between the macro issue of talent retention in an organization and the micro behavior of its member in the organization (Sarkar, 2018). This measure focuses on the level of importance placed by different employee groups in the organization. It should be noted that in the U.S., companies are finding it a challenge to balance growth and compensate talent, offering pay raises and other incentives to retain the talent they need to grow, according to the 2014 Compensation Best Practices Report from Payscale (Surveys, 2014).

Diversity \& Inclusion. Today's workplace has departed from the traditional hierarchical model and transitioned into flatter and less-structured paradigms. Accordingly, the means and methods of leadership development also are changing (Tavakoli, 2015). As organizations evolve, diversity and inclusion are becoming more integral to cultivating strong leaders and strong organizations. It is intended to be a shared responsibility but to what extent it is viewed as important to different stakeholder groups?

Drive Business Metrics. HR metrics can be a meaningful measures of HR performance in the context of total organization (Sen \& Haque, 2016). In today's competitive world, it has become very important to measure the HRM activities from return on HR investment point of view (Akthar, 2013). Therefore, what level of importance is placed on HR metrics in organizations?

Employee Engagement. Employee engagement represents a work-related state of mind characterized by feelings of vigor, fulfillment, enthusiasm, absorption and dedication. However, scholars are still ambivalent about its theoretical contribution to explaining the employee-organization relationship (Eldor \& Vigoda-Gadot, 2017). This measures seeks to identify the importance placed on employee engagement strategies in organizations.

Employee Retention. A study by Presbitero, Roxas, and Chadee (2016) highlights that superior HRM practices, by themselves, only have limited effects on employee retention. In today's business world, retention of valuable employees is one of the most critical issues confronting leaders. Employees have competencies that are critical for the survival of an organization. The HR department has to play a key role in designing the policies, practices and strategies which can enable an organization to retain the human resources who are 
contributing significantly to the business (Mwasaru \& Kazungu Kingi, 2015).

HR Cost Management. HR is more than a department: It is a set of broad-reaching activities that support the organization in managing its people. At many companies, some of the costs associated with providing these services do not show up as part of the HR budget, but are still part of the total investment in human capital (Rison \& Tower, 2005). To what extent do the stakeholder groups view HR cost management as important?

Human Capital Strategy. Capabilities are deployed through the human capital in the firm. Human capital is the knowledge, skills, and capabilities of individuals, which are often based on a person's education and experience (Hitt \& Ireland, 2002). Drawing on their human capital, managers make decisions and take actions, and employees perform prescribed tasks to implement the firm's strategies (Greer, Lusch, \& Hitt, 2017).

Learning \& Development. The value proposition for learning and talent development (LTD) is often challenged due to human resources' inability to demonstrate meaningful outcomes in relation to organizational needs and return-on-investment. The primary role of human resources (HR) and the learning and talent development (LTD) function is to produce meaningful outcomes to support organizational change, performance improvement and organizational impact (Ware, 2018)

Organizational Culture. Culture is extremely important for the functioning of companies and other organizations: from strategic change to daily management and how managers and employees relate and interact with customers to the way knowledge is created, shared, maintained and used (Alvesson, 2002). Organizational culture, or culture in general, is an abstract concept. Nevertheless, forces that are created in social and resulting organizational situations are strong. Cultural forces are strong because they often operate outside the consciousness of individuals (IlieŞ \& Metz, 2017).

Organizational Design. Organization design is a major factor determining an organization's performance and how the people work together in these organizations (Burton \& Obel, 2018). An organizational design must specify the fit between the structure of division of tasks in the organization with its coordination, or how to make these tasks work in concert. These tasks can be interdependent and uncertain. To design good organizations, we need empirical evidence about what is and exploration about what might be; we need a good theoretical basis for being able to generalize our knowledge.

Organizational Effectiveness. Organizational effectiveness is a company's long term ability to achieve consistently its strategic and operational goals (Fallón \& Brinkerhoff, 1996). Effective organizations tend to produce better quality products and are resilient in the face of adversity. Further, organizational theory has also produced a variety of models (rational goal, system resource, internal process, and participant satisfaction) pertaining to organizational effectiveness, the measures of organizational effectiveness being (a) productivity; (b) adaptability; and (c) efficiency, and other outcomes (Kataria, Rastogi, \& Garg, 2013).

Performance Management. Performance management refers to a broad range of activities or practices that an organization engages in to enhance the performance of a person or group, 
with the ultimate goal of improving organizational performance (DeNisi, 2000). In practice, performance management typically involves the continuous process of identifying, measuring, and developing the performance of individuals and groups in organizations (Gorman, Meriac, Roch, Ray, \& Gamble, 2017), and it involves providing both formal and informal performance-related information to employees.

Safety. Workplace safety is an important operational priority facing organizations. Although we know workplace accidents occur all too often, how employers can best reduce the number of accidents remains unclear(Lauver). The concept of a "safety climate" emphasizes the importance of how organizations manage health and safety in the workplace. It is important that managers consider that any changes made to the operations of a business will have an impact on workers' perceptions (Waheed, Ahsan, Ahmad, \& Ahmad, 2012).

Strategy Execution. The involvement that an organization's HR function has in the development and implementation of strategy-how much and what kind-is a critical determinant of its influence and the value it adds. There is a growing consensus among executives and researchers that human capital needs to be given more and better-informed consideration because it should be an important determinant of what strategies an organization can and should pursue (Lawler \& Boudreau, 2015).

Succession Planning. It is important for HR to build a business case for succession planning and to help their senior team put the necessary time and thought into the process. With executives' input and support, HR professionals can create career development plans to ensure that high-potential workers get the experience they need to be future leaders (Meinert, 2018). In the end, a carefully crafted succession plan will not only help a company prepare for the future, it will also help engage and retain top performers in the present.

Talent Acquisition. The general consensus is to recognize the importance of recruiting skilled individuals and devoting tremendous time, effort, and financial resources to employing the right people (Bugg, 2015).

Talent Management. No organization can survive with either a solely 'make' or 'buy' strategy (Gusain, 2017). Talent management is a delicate balance between the two. Most organizations do both talent acquisition and development in varying ratios, and within an organization, this ratio will fluctuate with market conditions, organizational strategy, state of the economy, and other factors. An optimal approach would be to use a combination of the two. The challenge is to figure out how much of each to use (Cappelli, 2008).

Union/Labor Relations. In the last century and before, HR grew out of the need for businesses to manage and work with labor unions. Labor unions grew in response to capitalism and the industrial revolution (Westmark, 2018). On a day to day basis, businesses needed a department to manage the ever-present issues and difficulties between management and labor. Labor relations demanded mechanisms to deal with labor grievances against management. As labor contracts became more complicated and sophisticated, HR's role increased. HR continues to participate in grievance committees and grievance procedures, but management demands that 


\section{Macrothink}

International Journal of Human Resource Studies

ISSN 2162-3058

2019, Vol. 9, No. 2

HR assist with bargaining talks over labor contracts. HR also reviews other companies' labor contracts and surveys these companies regarding salaries and wages (Westmark, 2018)

Wellness/Health Services. Investing in a healthy workforce is becoming paramount as empirical evidence continues to illustrate that wellness has a positive impact on worker productivity (Envick, 2012). At the same time, studies also show that there is an overall decline in the health of the American workforce with the continued rise in overweight and obesity rates. This is a problem that must be addressed by individuals, the government, communities, and employers alike (Envick, 2012).

Workforce Analytics. Workforce analytics can significantly enhance the ability of leaders and managers to achieve their operational and strategic objectives through more effective workforce management. However, capitalizing on these opportunities will require both HR and line managers to develop a comprehensive understanding of the workforce contributions to their firm's strategic success - and this understanding must be reflected in the workforce metrics and analytics they develop and deploy (Huselid, 2018).

Workforce Transformation. The paradigm shift in managing the living assets of organizations has witnessed a revolution in the past three decades. Human-Resources (HR) professionals now strive for corroborating the decisive capabilities of organizations driving business excellence. This trend signals a transformation in the way HR contributes to organizational objectives (P \& Malhotra, 2013).

\section{Results}

\section{Descriptive Statistics}

With all of the data combined, descriptive statistics were utilized in analyzing the data. Among the top five HR activities that were viewed as important by all stakeholders combined, i) Employee Engagement, ii) Employee Retention, iii) Talent Acquisition, iv) Organizational Culture, and v) Building the HR function ranked highest. Table 1.0 shows all of the variables with the mean scores. Talent management, coaching, learning and development, and human capital strategy were also viewed as important by all respondents combined.

Looking back at HR priorities over the past years, there is definitely an emphasis being placed on the strategic aspects of HR. Furthermore, with an unemployment rate of less than $5 \%$ nationally, there is a sense of urgency within organizations to retain the current talent and be able to build strategies to attract qualified talent to the organization. 
Table 1.0. Descriptive Statistics of All Variables

\begin{tabular}{l|c|c|c|c|c}
\hline Variable & $\mathbf{N}$ & $\mathbf{N}^{*}$ & Mean & $\begin{array}{c}\text { SE } \\
\text { Mean }\end{array}$ & StDev \\
\hline Employee Engagement & 150 & 3 & 4.49 & 0.05 & 0.67 \\
\hline Employee Retention & 150 & 3 & 4.46 & 0.05 & 0.66 \\
\hline Talent Acquisition & 149 & 4 & 4.42 & 0.05 & 0.63 \\
\hline Organizational Culture & 149 & 4 & 4.39 & 0.06 & 0.76 \\
\hline Build HR Function & 148 & 5 & 4.34 & 0.06 & 0.73 \\
\hline Learning \& Development & 150 & 3 & 4.32 & 0.06 & 0.71 \\
\hline Coach and Build Executive & 149 & 4 & 4.30 & 0.07 & 0.87 \\
Manag & 149 & 4 & 4.30 & 0.06 & 0.73 \\
\hline Talent Management & 150 & 3 & 4.29 & 0.06 & 0.74 \\
\hline Human Capital Strategy & 148 & 5 & 4.27 & 0.06 & 0.73 \\
\hline Diversity \& Inclusion & 150 & 3 & 4.24 & 0.07 & 0.82 \\
\hline Organizational Effectiveness & 150 & 3 & 4.24 & 0.07 & 0.80 \\
\hline Succession Planning & 149 & 4 & 4.21 & 0.05 & 0.67 \\
\hline Compensation & 149 & 4 & 4.15 & 0.08 & 0.92 \\
\hline Safety & 150 & 3 & 4.13 & 0.06 & 0.77 \\
\hline Performance Management & 150 & 3 & 4.03 & 0.07 & 0.83 \\
\hline Wellness/Health Services & 150 & 3 & 4.01 & 0.08 & 0.92 \\
\hline Strategy Execution & 148 & 5 & 3.99 & 0.07 & 0.86 \\
\hline Organizational Design & 150 & 3 & 3.99 & 0.07 & 0.82 \\
\hline Workforce Analytics & 149 & 4 & 3.95 & 0.08 & 0.94 \\
\hline Drive Business Metrics & 149 & 4 & 3.94 & 0.07 & 0.83 \\
\hline HR Cost Management & 150 & 3 & 3.91 & 0.07 & 0.87 \\
\hline Workforce Transformation & 150 & 3 & 3.82 & 0.08 & 0.95 \\
\hline Board Relations & 149 & 4 & 3.76 & 0.08 & 1.02 \\
\hline Union/Labor Relations & & & & & \\
\hline & 159 & \\
\hline
\end{tabular}

\section{Importance of the Respective HR Activities}

The factors viewed as least important were i) Labor Relations, ii) Board Relations, iii) Workforce Transformations, iv) HR Cost Management, and v) Drive Business Metrics. These results may not be as surprising given the diminishing role of unions and lower membership to unions. While academicians and senior HR executives have argued the point of evaluating HR metrics, it has not been a foremost priority for HR professionals. Workforce transformation and the change management initiatives are viewed as a part of the strategic interventions but not viewed as a priority. Board relations ranked among the lower variables which can be explained through the perception that it is not a general HR responsibility. There is typically a reporting relationship between the CHRO and the CEO, but participants generally did not view it as a priority. 
Diversity, succession planning, compensation, performance, and safety were all ranked in the middle. These factors are viewed as important and as necessities. They are strategies that are inherently critical.

An analysis of the correlation table as displayed in Table 2.0. There are numerous relatively strong relationships among several variables.

Table 2.0. Correlation Among Variables

\begin{tabular}{|c|c|c|c|c|c|c|c|c|c|c|c|c|c|}
\hline & $\begin{array}{l}\text { Build HR } \\
\text { Functio }\end{array}$ & $\begin{array}{l}\text { Coach and } \\
\text { Build }\end{array}$ & $\begin{array}{c}\text { Compensati } \\
\text { on }\end{array}$ & $\begin{array}{l}\text { Diversity \& } \\
\quad \text { Incl }\end{array}$ & $\begin{array}{c}\text { Drive } \\
\text { Business M }\end{array}$ & $\begin{array}{l}\text { Employee } \\
\text { Engagem }\end{array}$ & $\begin{array}{c}\text { Employee } \\
\text { Retenti }\end{array}$ & $\begin{array}{c}\text { Learning \& } \\
\text { Devel }\end{array}$ & $\begin{array}{c}\text { Organizat } \\
\text { ional C }\end{array}$ & $\begin{array}{c}\text { Organizat } \\
\text { ional E }\end{array}$ & $\begin{array}{l}\text { Performa } \\
\text { nce Mana }\end{array}$ & $\begin{array}{c}\text { Strategy } \\
\text { Executi }\end{array}$ & :cession Plè \\
\hline Coach and Build & 0.438 & & & & & & & & & & & & \\
\hline Compensation & 0.181 & 0.22 & & & & & & & & & & & \\
\hline Diversity \& Inclusion & 0.039 & 0.099 & 0.23 & & & & & & & & & & \\
\hline Drive Business M & 0.294 & 0.416 & 0.191 & 0.267 & & & & & & & & & \\
\hline Employee Engagemen & 0.108 & 0.148 & 0.16 & 0.271 & 0.214 & & & & & & & & \\
\hline Employee Retention & 0.087 & 0.084 & 0.271 & 0.253 & 0.149 & 0.585 & & & & & & & \\
\hline Learning \& Dev. & 0.183 & 0.184 & 0.355 & 0.229 & 0.271 & 0.431 & 0.361 & & & & & & \\
\hline Organizational Change & 0.237 & 0.412 & 0.289 & 0.258 & 0.535 & 0.354 & 0.279 & 0.454 & & & & & \\
\hline Organizational Effectiv & 0.114 & 0.414 & 0.289 & 0.258 & 0.529 & 0.384 & 0.356 & 0.481 & 0.586 & & & & \\
\hline Performance Manager & 0.229 & 0.218 & 0.283 & 0.153 & 0.428 & 0.39 & 0.366 & 0.35 & 0.357 & 0.469 & & & \\
\hline Strategy Execution & 0.231 & 0.507 & 0.248 & 0.244 & 0.632 & 0.254 & 0.226 & 0.336 & 0.55 & 0.612 & 0.449 & & \\
\hline Succession Planning & 0.209 & 0.263 & 0.295 & 0.179 & 0.306 & 0.379 & 0.35 & 0.396 & 0.359 & 0.476 & 0.381 & 0.47 & \\
\hline Talent Management & 0.172 & 0.24 & 0.379 & 0.27 & 0.39 & 0.386 & 0.442 & 0.487 & 0.406 & 0.575 & 0.439 & 0.47 & 0.593 \\
\hline
\end{tabular}

i) Coaching and building a strong HR department. Coaching executives has long been a value-added activity of HR executives. It is seen as a strategic intervention helping other senior leaders be more effective leaders through understanding, influencing, and even predicting employees' behaviors. Therefore, whenever, HR executives can effectively coach other executives, such efforts are viewed positively and value-added.

ii) Drive Business Metrics and Coaching. Coaching is typically helping to unleash the strengths of others so whenever HR can be coaches, there tends to be stronger metrics aligned to organizational outcomes. The results clearly highlight such correlation. In addition, interviews with Senior Leaders highlighted the need for stronger metrics and for leaders coaching and mentoring HR professionals to use more outcome-based HR practices and measures.

iii) Organizational change and metrics. One of the pitfalls of the HR function has been the inability or focused efforts in measuring HR activities impact on results. There are constant planned change interventions. All stakeholder groups indicated strong emphasis on effectively planning, implementing, and evaluating change management strategies. The stronger coefficient of correlation indicates the emphasis on measuring changes being implemented and the linkages to achieving intended outcomes.

iv) Employee engagement and employee retention, learning and development, organizational effectiveness, performance management, and talent management. Valuing employees, investing in human capital, and managing performance effectively all have strong correlations. 


\section{Macrothink}

Do HR Professionals, Managers, and Senior Executives View HR Activities Differently?

What is the fundamental role of HR? In the end, HR serves to contribute to an organization's success and ensure employees' well-being. It is about helping the organization compete more effectively and beating the competition. It is about being able to attract and retain employees and helping employees give their best. The results in Figure 1.0 highlight the extent to which the respective HR activities are viewed as contributing to an organization's success.

Figure 1.0. Comparison of Responses

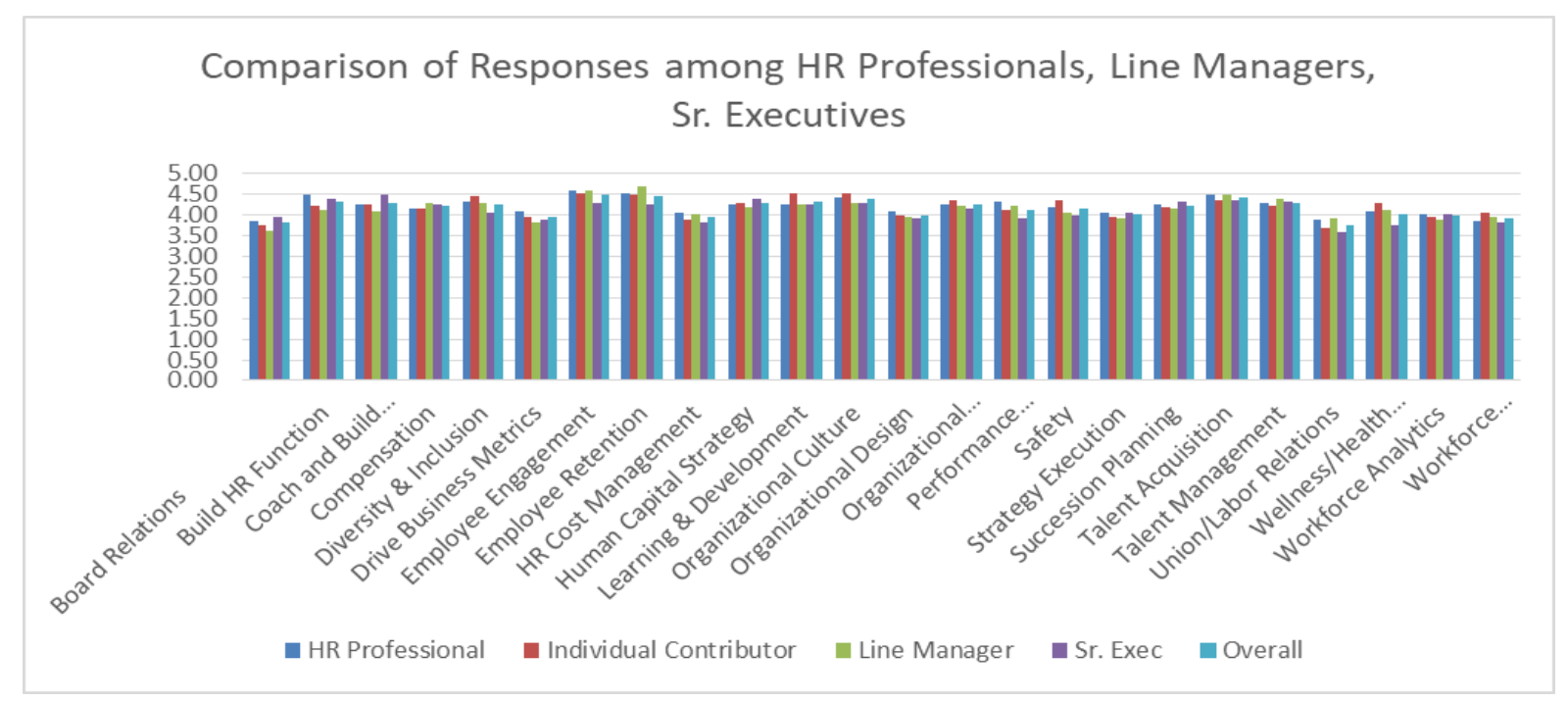

Figure 2.0. Education

Q26 What level of education have you competed?

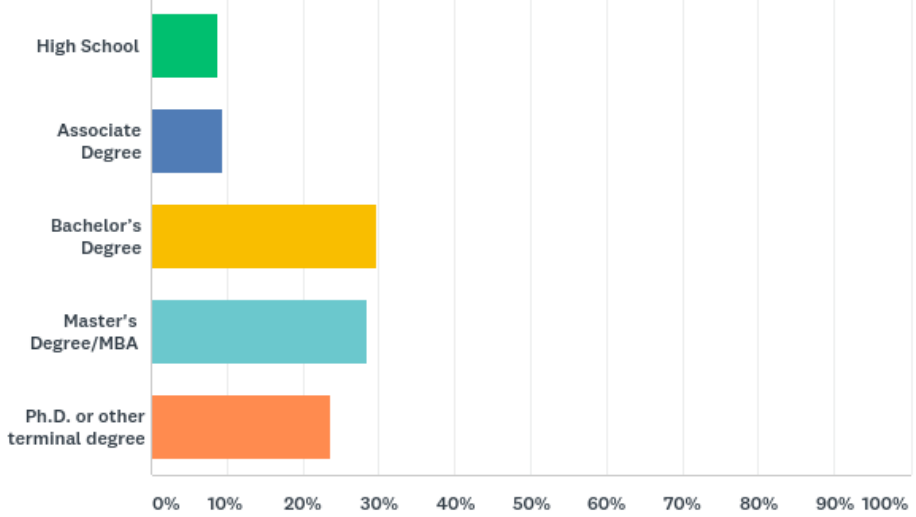

There were numerous significant differences among the HR Professionals, Senior Executives, Line Managers, and Individual Contributors. These are highlighted.

Building the HR Function - There was general consensus that building the HR function is a priority for the organizations. The overall score was 4.34 , with senior executives placing immense value at 4.4 . 


\section{Macrothink}

International Journal of Human Resource Studies ISSN 2162-3058 2019, Vol. 9, No. 2

Diversity and Inclusion - Senior executives ranked Diversity and Inclusion at 4.06 as compared to HR at 4.33 and an overall score of 4.27. This difference in priority could create a dissonance where HR could be working on creating a more diverse workplace but senior leadership does not necessarily view this strategy as a main priority.

Coach and Build Executive Management Team - Except for line managers, coaching and building an effective executive management team was viewed as relatively important with an overall score of 4.30 .

Compensation - All stakeholder groups rated compensation as relatively high with an overall score of 4.21. HR professionals ranked compensation at 4.15 which was the lowest of the ratings.

Drive Business Metrics - Driving business metrics was not ranked the highest. The overall score was 3.95, with senior executives rating at 3.89 and line managers 3.81 . This was relatively surprising as there is a need to measure what we do as espoused in the literature and from organizational strategies.

Employee Engagement - Employee engagement was definitely one of the highest ranked priorities with an overall score of 4.49 with little variation among the respective groups. There was a clear and urgent emphasis on this factor.

Employee Retention - Retaining employees was a significant priority with an overall score of 4.46. Line managers ranked retention at 4.69. Senior managers' overall priority was at 4.26 .

HR Cost Management - HR Cost management was not a foremost priority with an overall score of 3.94 .

Human Capital Strategy - The overall score for human capital strategy was 4.29. Senior executives placed an even higher value at 4.38, with HR at 4.24.

Learning and Development - There is a high emphasis on employee learning and development with an overall score of 4.32. Individual contributors ranked L\&D the highest at a score of 4.54 reflecting one of the expectations of employees to always be learning.

Organizational Culture - There was consensus that organizational culture is critical with an overall score of 4.39 .

Organization Design - Organizational design was not ranked really high with an overall score of 3.99, with little variation among the different stakeholder groups.

Organizational Effectiveness - Planned changes, alignment, and other org. effectiveness components had an overall score of 4.24, with senior executives ranking it the lowest at 4.17.

Talent Acquisition and Talent Management - Both of these strategies were rated relatively high by all groups. The overall scores were 4.42 and 4.30 , respectively. Given the lower unemployment rates across the country, attracting and retaining human capital is of pivotal importance. 


\section{I Macrothink}

International Journal of Human Resource Studies

ISSN 2162-3058

2019, Vol. 9, No. 2

\section{Discussion and Conclusion}

As Ulrich (2018) explained in a recent LinkedIn post, the business partner concept has dramatically evolved (transformed, been disrupted, evolved, or whatever word you choose) from roles and outcomes to a logic of how HR delivers value to employees, organizations, customers, investors, and communities through individual talent (competence, workforce, people), leadership throughout an organization, and organization capabilities (culture, workplace, systems). The findings of this research support this evolution regarding HR's priorities as identified by senior executives, HR professionals, line managers, and individual contributors. Ultimately, HR must focus on the competence of employees, the organization's ability to win, and human capital.

Contradictory to Wright, McMahan, Snell, and Gerhart (2001) this study found more of an alignment among priorities and the emphasis being placed on various HR strategies among senior executives and HR. The 2001 study examined the importance and effectiveness of HR from the viewpoints of both top-level line and HR executives. Their results indicated that both line and HR executives recognize the potential importance of HR activities to the firm's competitive advantage, and that both groups agree regarding HR's strengths and weaknesses in delivering those services. Their results also point to the fact that line executives do not give nearly as high marks as HR executives do when it comes to evaluating HR's effectiveness. Such results are contradicted in this study, highlighting a more aligned set of priorities among HR, senior executives, line managers, and individual contributors.

Maybe it is time for the HR profession to recognize and appreciate progress that has been made. While individual experiences may differ, our data clearly shows that HR professionals have become more competent and valued over the last 30 years. Instead of bemoaning what HR professionals lack, maybe it is time to relish the progress that has been made. Do these results imply that HR "has arrived?" No, there is always more to do, but the base for moving forward is strong and getting stronger (Ulrich, Kryscynski, Ulrich, \& Brockbank, 2017).

\section{References}

Akhtar, S., Ding, D. Z., \& Ge, G. L. (2008). Strategic HRM practices and their impact on company performance in Chinese enterprises. Human Resource Management, 47(1), 15-32. https://doi.org/10.1002/hrm.20195

Akthar, P. (2013). IMPORTANCE OF MEASURING HR'S EFFECTIVENESS: A DRIVE TO HR METRICS. CLEAR International Journal of Research in Commerce \& Management, 4(10), 78-81.

Alvesson, M. (2002). Understanding Organizational Culture. London: AGE Publications. https://doi.org/10.4135/9781446280072

Barney, J. (1991). Firm Resources and Sustained Competitive Advantage. Journal of Management, , 17(1), 99-120. https://doi.org/10.1177/014920639101700108 
Becker, B., \& Huselid, M. (1998). High performance work systems and firm performance: A synthesis of research and managerial implications. Research in Personnel and Human Resources Management, 16, 53-101.

Becker, B., \& Huselid, M. (2006). Strategic human resources management: Where do we go from here? Journal of Management, 32(6), 898-925. https://doi.org/10.1177/0149206306293668

Becker, B., Huselid, M., \& Ulrich, D. (2001). The HR Scorecard: Linking people, Strategy, and Performance. Boston, MA: Harvard Business School Press.

Bugg, K. k. b. g. c. (2015). Best Practices for Talent Acquisition in 21st-Century Academic Libraries. Library Leadership \& Management, 29(4), 1-14.

Burton, R. M., \& Obel, B. (2018). The science of organizational design: fit between structure and coordination. Journal of Organization Design, 7(1), 1-13. https://doi.org/10.1186/s41469-018-0029-2

Cappelli, P. (2008). Talent Management for the Twenty-First Century. HBR. Retrieved from https://hbr.org/2008/03/talent-management-for-the-twenty-first-century

Chen, J. J. (2015). The Emerging Role of HR in the Boardroom. People \& Strategy, 38(2), $36-43$.

DeNisi, A. (2000). Performance appraisal and performance management. San Francisco, CA: Jossey-Bass.

Drucker, P. (2004). What Makes an Effective Executive? Harvard Business Review.

Eldor, L., \& Vigoda-Gadot, E. (2017). The nature of employee engagement: rethinking the employee-organization relationship. International Journal of Human Resource Management, 28(3), 526-552. https://doi.org/10.1080/09585192.2016.1180312

Emeagwal, L., \& Ogbonmwan, K. O. (2018). MAPPING THE PERCEIVED ROLE OF STRATEGIC HUMAN RESOURCE MANAGEMENT PRACTICES IN SUSTAINABLE COMPETITIVE ADVANTAGE. Academy of Strategic Management Journal, 17(2), 1-19.

Envick, B. R. (2012). INVESTING IN A HEALTHY WORKFORCE: THE IMPACT OF PHYSICAL WELLNESS ON PSYCHOLOGICAL WELL-BEING AND THE CRITICAL IMPLICATIONS FOR WORKER PERFORMANCE. Academy of Health Care Management Journal, 8(1/2), 21-32.

Fallón, T., \& Brinkerhoff, R. O. (1996). Framework for Organizational Effectiveness. Paper presented at the American Society for Training and Development International Conference.

Glamuzina, M. (2015). LEVELS OF LEADERSHIP DEVELOPMENT AND TOP MANAGEMENT'S EFFECTIVENESS: IS THERE A CLEAR-CUT RELATIONSHIP? RAZINE RAZVIJENOSTI VODSTVA I UČINKOVITOST TOP MENADŽMENTA: POSTOJI LI JASNA POVEZANOST?, 20(1), 89-131. 
Gorman, C. A., Meriac, J. P., Roch, S. G., Ray, J. L., \& Gamble, J. S. (2017). An exploratory study of current performance management practices: Human resource executives' perspectives. International Journal of Selection \& Assessment, 25(2), 193-202. https://doi.org/10.1111/ijsa.12172

Greer, C. R., Lusch, R. F., \& Hitt, M. A. (2017). A SERVICE PERSPECTIVE FOR HUMAN CAPITAL RESOURCES: A CRITICAL BASE FOR STRATEGY IMPLEMENTATION. Academy of Management Perspectives, 31(2), 137-158. https://doi.org/10.5465/amp.2016.0004

Gusain, N. (2017). TALENT ACQUISITION VS DEVELOPMENT: WITH A FOCUS ON LEADERSHIP DEVELOPMENT PROGRAMS. Cornell HR Review, 1-4.

Gyton, G. (2017). "YOUR EMPLOYEES ARE THE PEOPLE WHO MAKE YOU WIN": Organisations are too focused on great players, says HR guru Dave Ulrich - it's time to start playing a team game. In (pp. 40-41): Haymarket Media Group Ltd.

Halawi, L. A., Mccarthy, R. V., \& Aronson, J. E. (2008). An Empirical Investigation of Knowledge Management Systems success. Journal of Computer Information Systems, 121-136.

Hitt, M., \& Ireland, R. (2002). The essence of strategic leadership: Managing human and social capital. Journal of Leadership \& OrganizationalStudies, 9, 3-14. https://doi.org/10.1177/107179190200900101

Huselid, M. A. (2018). The science and practice of workforce analytics: Introduction to the <italic $>$ HRM</italic> special issue. Human Resource Management, 57(3), 679-684. https://doi.org/10.1002/hrm.21916

IlieŞ, L., \& Metz, D. (2017). THE LINK BETWEEN ORGANIZATIONAL CULTURE AND ORGANIZATIONAL PERFORMANCE - A LITERATURE REVIEW. Managerial Challenges of the Contemporary Society, 10(1), 35-40.

Jackson, S. E., \& Schuler, R. S. (1987). Linking Competitive Strategies with Human Resource Management Practices. Academy of Management Perspectives, 1(3).

Jamrog, J. J., \& Overholt, M. H. (2004). Building a Strategic HR Function: Continuing the Evolution. Human Resource Planning, 27(1), 51-62.

Kataria, A., Rastogi, R., \& Garg, P. (2013). Organizational Effectiveness as a Function of Employee Engagement. South Asian Journal of Management, 20(4), 56-73.

Krausert, A. (2017). HR differentiation between professional and managerial employees: Broadening and integrating theoretical perspectives. Human Resource Management Review, 27(3), 442-457. https://doi.org/10.1016/j.hrmr.2016.11.002

Laine, P., Stenvall, J., \& Tuominen, H. (2017). A Strategic role for HR: is it a competence issue? Nordic Journal of Business, 66(1), 29-48. 
Lauver, K. (2004). HR SAFETY PRACTICES AND ORGANIZATIONAL SAFETY OUTCOMES.

Lawler, E. E., \& Boudreau, J. W. (2015). Global Trends in Human Resource Management : A Twenty-Year Analysis. Stanford, California: Stanford Business Books.

Meinert, D. (2018). TOMORROW'S LEADERS: A strong succession plan can strengthen your organization. HR Magazine, 63(6), 18-19.

Mitchell, R., Obeidat, S., \& Bray, M. (2013). The Effect of Strategic Human Resource Management on Organizational Performance: The Mediating Role of High-Performance Human Resource Practices. Human Resource Management, 52(6), 899-921. https://doi.org/10.1002/hrm.21587

Mwasaru, H., \& Kazungu, K. W. (2015). EFFECTS OF EMPLOYEE RETENTION STRATEGIES ON ORGANISATIONAL COMPETITIVE ADVANTAGE IN THE HOTEL INDUSTRY IN MOMBASA COUNTY. CLEAR International Journal of Research in Commerce \& Management, 6(3), 1-4.

Nadler, M., \& Nadler, D. (2015). The HR Opportunity in the Boardroom: How to Become a Trusted Advisor to the Board. People \& Strategy, 38(2), 22-27.

P, S., \& Malhotra, S. (2013). Challenges and Emerging Trends in Human Resource Management. International Journal of Business Anthropology, 4(2), 85-100.

Presbitero, A., Roxas, B., \& Chadee, D. (2016). Looking beyond HRM practices in enhancing employee retention in BPOs: focus on employee-organisation value fit. International Journal of Human Resource Management, 27(6), 635-652. https://doi.org/10.1080/09585192.2015.1035306

Rison, R. P., \& Tower, J. (2005). How to Reduce the Cost of HR and Continue to Provide Value. Human Resource Planning, 28(1), 14-17.

Sarkar, J. (2018). Linking Compensation and Turnover: Retrospection and Future Directions. Journal of Organizational Behavior, 17(1), 43.

Sen, A., \& Haque, S. (2016). HR Metrics and the Financial Performance of a Firm. Journal of Management Research (09725814), 16(3), 177-184.

Stopper, W. G. (2005). The HRPS Learning Agenda: A Thought Leader Retrospective. Human Resource Planning, 28(1), 7-10.

Surveys. (2014). Surveys Examine 2014 Compensation Trends in U.S., Globally (10674551). Retrieved from http://search.ebscohost.com/login.aspx?direct=true \&db=mfi\&AN=95705674\&site=ehost-live \&scope $=$ site

Tavakoli, M. (2015). DIVERSITY \& INCLUSION drive success for today's leaders. TD: Talent Development, 69(5), 46. 


\section{Macrothink}

International Journal of Human Resource Studies

ISSN 2162-3058 2019, Vol. 9, No. 2

Ulrich, D., Kryscynski, D., Ulrich, M., \& Brockbank, W. (2017). Victory Through Organization.

Waheed, M. S., Ahsan, M., Ahmad, S. R., \& Ahmad, A. (2012). The Impact of Safety Climate on Organizational Commitment (Affective, Normative and Continuance). Proceedings of the Northeast Business \& Economics Association, 335-339.

Ware, I. (2018). Aligning learning and talent development performance outcomes with organizational objectives: A proposed. (79), ProQuest Information \& Learning, Retrieved from

http://search.ebscohost.com/login.aspx?direct=true \&db=psyh\&AN=2017-54449-014\&site=e host-live\&scope=site Available from EBSCOhost psyh database.

Westmark, F. (2018). Labor Relations \& Human Resource Management. In (pp. 1-1): Great Neck Publishing.

Wright, P., Gardner, T., Moynihan, L., \& Allen, M. (2005). The relationship between HR practices and firm performance: Examining causal order. Personnel Psychology, 58(2), 409-446. https://doi.org/10.1111/j.1744-6570.2005.00487.x

Wright, P., Nyberg, A. J., Schepker, D. J., Cragun, O. R., \& Ulrich, M. D. (2016). The Changing Chief Human Resources Officer Role - Results of the 2016 HR@ Moore Survey of Chief HR Officers. Center for Executive Succession.

Wright, P. M., McMahan, G. C., Snell, S. A., \& Gerhart, B. (2001). COMPARING LINE AND HR EXECUTIVES' PERCEPTIONS OF HR EFFECTIVENESS: SERVICES, ROLES, AND. Human Resource Management, 40(2), 111. https://doi.org/10.1002/hrm.1002

Younger, J., \& Ulrich, D. (2011). Stress Testing HR Strategy and Effectiveness. The RBL Group, 1.

\section{Appendix}

Please rate the level to which you view the level of importance for the respective HR activities. Please use the scale of $1-5$ with 1 being not important to 5 being very important.

\section{$\underline{\text { HR Activities }}$}

\begin{tabular}{llllll} 
Board Relations & \multicolumn{1}{c}{2} & 3 & 4 & 5 & \\
Build HR Function & 1 & 2 & 3 & 4 & 5 \\
Coach and Build EMT & 1 & 2 & 3 & 4 & 5 \\
\cline { 2 - 5 } Compensation & 1 & 2 & 3 & 4 & 5 \\
Diversity \& Inclusion & 1 & 2 & 3 & 4 & 5 \\
Drive Business Metrics & 1 & 2 & 3 & 4 & 5 \\
Employee Engagement & 1 & 2 & 3 & 4 & 5
\end{tabular}




\section{Macrothink}

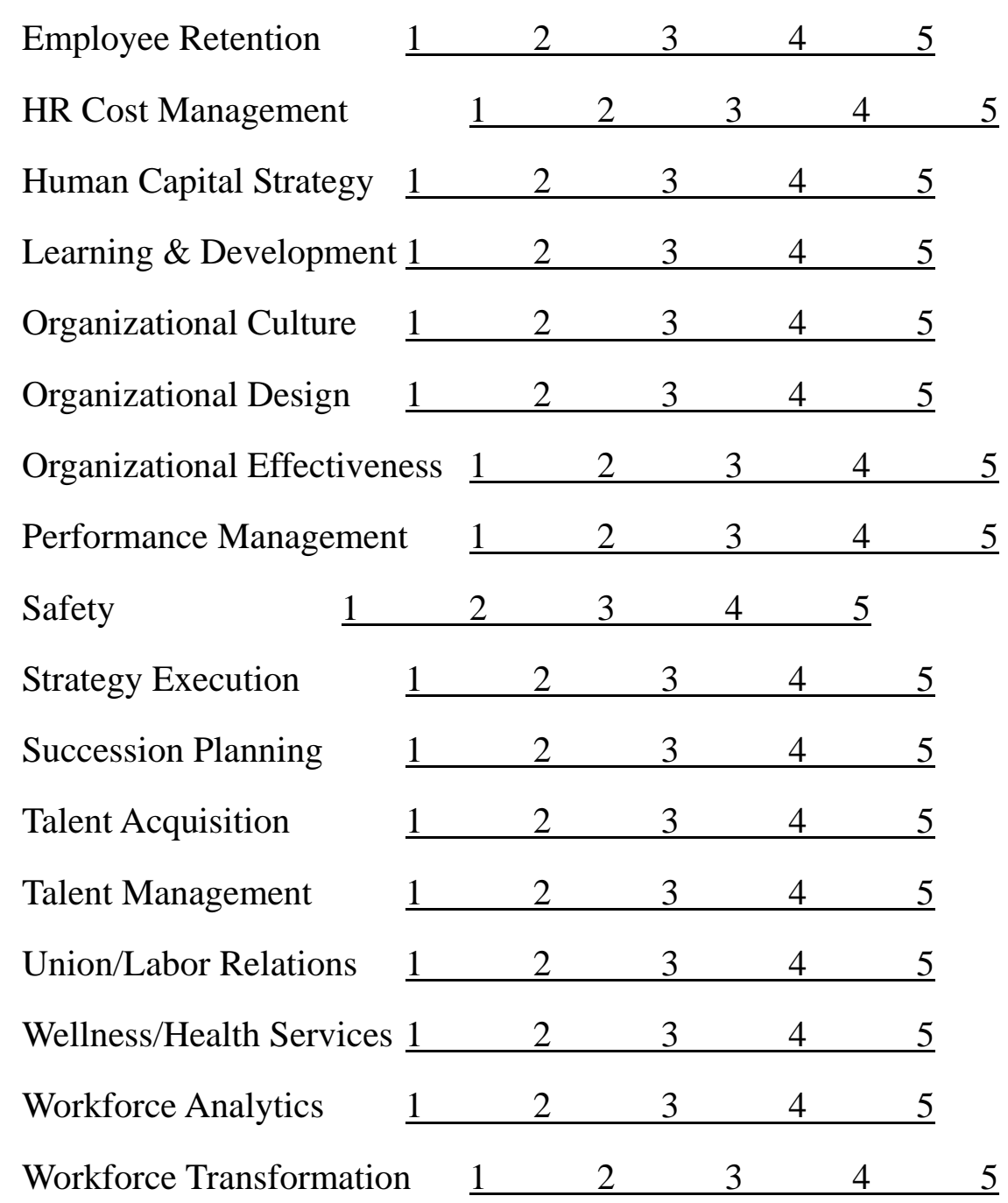

\section{Demographics}

Which of the following best describes your professional role?

- HR Professional

- Senior Executive

- Line Manager

- Individual Contributor

What level of education have you competed?

- High School

- Associate Degree

- Bachelor's Degree

- Master's/MBA

- Ph.D. or other terminal degree 


\section{Copyright Disclaimer}

Copyright for this article is retained by the author(s), with first publication rights granted to the journal.

This is an open-access article distributed under the terms and conditions of the Creative Commons Attribution license (http://creativecommons.org/licenses/by/4.0/). 